\title{
Mobilizing the Masses
}

Street Vendors, Political Contracts, and the Role of Mediators in Yogyakarta, Indonesia

\author{
Sheri Lynn Gibbings \\ Wilfrid Laurier University \\ sgibbings@wlu.ca \\ Elan Lazuardi \\ Universitas Gadjah Mada \\ elan.lazuardi@ugm.ac.id \\ Khidir Marsanto Prawirosusanto \\ Universitas Gadjah Mada \\ khidir.marsanto.p@mail.ugm.ac.id
}

\begin{abstract}
This article explores how a major street vendor organization, APKLI, negotiated its political agency during the New Order and post-Soeharto eras in Indonesia. Tracing the formation of the organization to its current existence, the article argues that APKLI has relied on mediators - both street vendor leaders and others with close ties to the state, other organizations, and/or political parties - to negotiate for street vendors' recognition and support. It then describes how APKLI National sought to engage in electoral populism during the 2014 presidential election by promising to support a particular candidate in exchange for greater recognition and protection of street vendors. We argue that despite APKLI's attempt to generate an 'imagined community' (Anderson 1983) of street vendors across the archipelago, many of its own district branches as well as individual street vendors supported local patrons who would more directly influence their immediate future. Others did not want to support a single political party, and preferred to maintain a neutral stance.
\end{abstract}

(C) SHERI LYNN GIBBINGS, ELAN LAZUARDI AND KHIDIR MARSANTO PRAWIROSUSANTO,

2017 | DOI: $10.1163 / 22134379-17301004$

This is an open access article distributed under the terms of the prevailing CC-BY-NC license at the time of publication. 


\section{Keywords}

street vendors - political contracts - elections - brokers - patron-client relationships Indonesia

\section{Introduction}

On a sunny day in May 2013, Suhardi ${ }^{1}$ sat behind his desk at the office of the Asosiasi Pedagang Kaki Lima Indonesia (APKLI, Association of Indonesian Street Vendors) at the north end of Malioboro Street, a famous shopping district for tourists in Yogyakarta City, Indonesia. Suhardi is the leader of APKLI's Dewan Pimpinan Daerah (DPD, Regional Representative Council) for Yogyakarta City, but also the long-time leader of Tri Dharma, a powerful street vendor organization on Malioboro Street. The APKLI office was small but tidy, with one desk (Figure 1). Pictures of the mayor, vice-mayor, governor, and leader of APKLI National, Ali Mahsun, hung on the wall. As we spoke about recent changes street vendors faced, Suhardi explained that Peraturan Menteri Dalam Negeri Republik Indonesia Nomor 41 Tahun 2012 tentang Pedoman Penataan dan Pemberdayaan Pedagang Kaki Lima (Ministry of Home Affairs Regulation no. 41/2012 concerning the Coordination and Empowerment of Street Vendors) meant that street vendors were being discussed at the level of national ministers and the president. ' 'Previously, this was far from the case, and there was an even greater difference during the Soeharto era', he said, regarding the treatment of traders. ${ }^{3}$ Suhardi's comments were not unlike those of other traders we spoke with, who discussed with excitement how street vending was becoming not just a local issue, but also a national one.

1 All names are pseudonyms except for mayors, district heads, and the national leaders of APKLI.

2 There were actually two regulations passed: Peraturan Presiden Republik Indonesia Nomor 125 Tahun 2012 tentang Koordinasi Penataan dan Pemberdayaan Pedagang Kaki Lima or Presidential Regulation no. 125/2012, concerning the Coordination of the Organization and Empowerment of Street Vendors, and Peraturan Menteri Dalam Negeri Republik Indonesia Nomor 41 Tahun 2012 tentang Pedoman Penataan dan Pemberdayaan Pedagang Kaki Lima or the Ministry of Home Affairs Regulation no. 41/2012, concerning the Guidelines for the Coordination and Empowerment of Street Vendors.

3 Suhardi, interview with Sheri, 23-7-2013, Yogyakarta. 


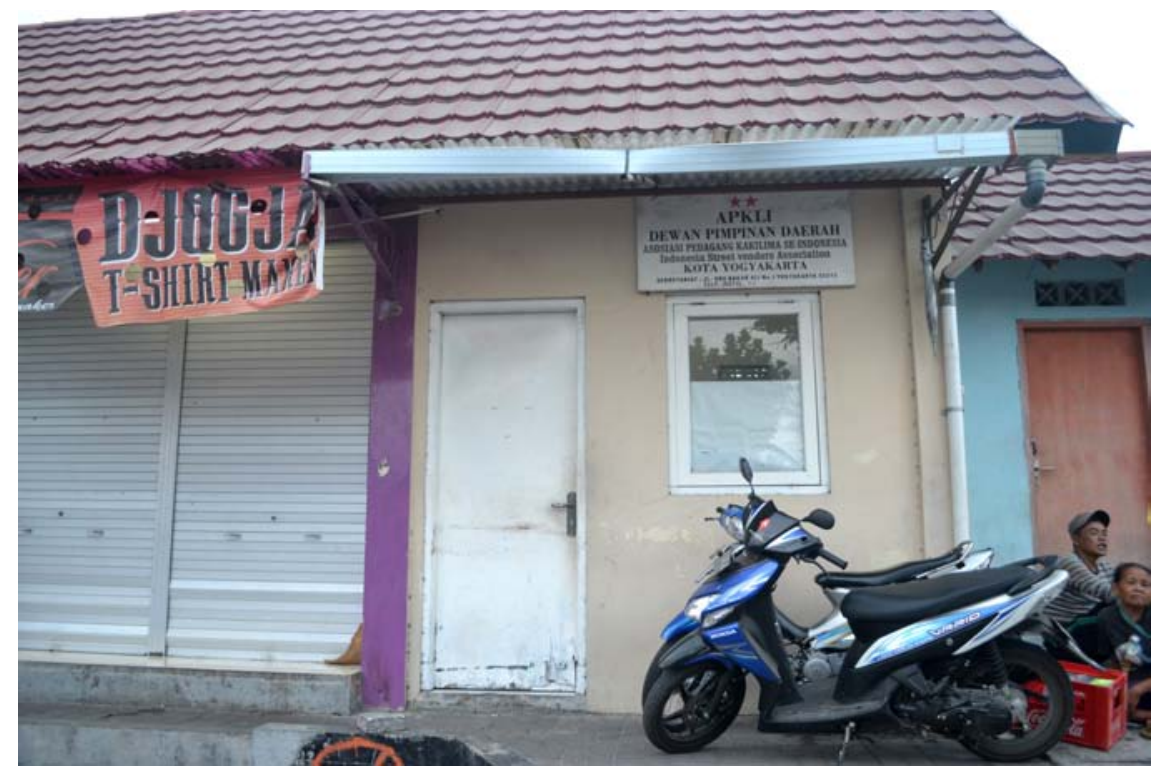

FIGURE 1 APKLI DIY city office

Suhardi became the leader for APKLI Yogyakarta City in 2008, and worked alongside other district leaders in the Daerah Istimewa Yogyakarta (DIY, Province of Yogyakarta). He was central to gathering the members of APKLI Yogyakarta to support Haryadi Suyuti's mayoral campaign in the last election (for the period of 2012-2017). As the main spokesperson for the city branch of APKLI, Suhardi announced in newspapers that they planned to support Haryadi because, as vice-mayor alongside Herry Zudianto in an earlier period, he had achieved a number of things. 'These two leaders, Herry-Haryadi, were felt by the community', Suhardi explained. Haryadi had communicated regularly with the street vendor association. ${ }^{4}$ Consequently, with a membership of approximately 6,651 people, APKLI made a political contract (kontrak politik) with Haryadi. 'The potential of our voices is real', Wawan, another leader of APKLI,

4 In 2006, Herry Zudianto (Partai Amanat Nasional [PAN, National Mandate Party]) and Haryadi Suyuti (Partai Demokrasi Indonesia Perjuangan [PDI-P, Indonesian Democratic PartyStruggle) ran and were elected as mayor and vice-mayor of Yogyakarta City. In 2011, the domination of PAN in Yogyakarta City ended, and Haryadi Suyuti (PDI-P) was elected mayor with Imam Priyono (Golongan Karya [Golkar, Functional Groups]) as vice-mayor. They won against Achmad Hanafi Rais, who is the son of Amien Rais, a leader of Muhammadiyah-one of the biggest Islamic organizations in Indonesia-and one of the founders of PAN. 
explained in a newspaper. ${ }^{5}$ On the nineteenth birthday of APKLI, the elected mayor Haryadi Suyuti confirmed in a statement to the press that 'Within our working document [we have agreed that] there will not be a clearance of street vendors.' ${ }^{6}$

APKLI is not just important as an organization during mayoral elections; it is also seeking to be a larger force at the national level. During the 2014 Indonesian presidential election, the national body of APKLI under its leader, Ali Mahsun, decided to support Prabowo-Hatta (running with the Gerindra party) after a meeting at the end of April. ${ }^{7}$ APKLI National claimed to support Hatta Radjasa (who was running for vice-president), in particular, because as minister for economic affairs he had helped to pass the Peraturan Presiden Republik Indonesia Nomor 125 Tahun 2012 tentang Koordinasi Penataan dan Pemberdayaan Pedagang Kaki Lima (Presidential Regulation no. 125/2012, concerning the Coordination and Empowerment of Street Vendors). ${ }^{8}$ He was also on the Dewan Kehormatan (Board of Trustees) of AP KLI, and claimed that street vendors should be empowered, not evicted. ${ }^{9}$ APKLI National was also disappointed with how Joko Widodo (another presidential candidate who was the governor of Jakarta at the time) had forced street vendors to move from Blok $\mathrm{G}$ in Tanah Abang, the biggest textile market in Southeast Asia. Ali Mahsun said that when Widodo had relocated these traders, he had damaged their dignity. ${ }^{10}$ It was also claimed that Widodo did not meet with the traders enough during the process. ${ }^{11}$ For these reasons, a political contract was made between

'Kuwat terkuat di koalisi Mataram: PKL ingin Haryadi jadi penerus Herry', Radar Jogja, 313-2011, https://issuu.com/radarjogja/docs/radar_jogja_31_maret_2011 (accessed 11-6-2014).

6 'Pemkot janji tak gusur PKL', Joglosemar, 31-1-2012, http://edisicetak.joglosemar.co/berita/ pemkot-janji-tak-gusur-pkl-66310.html (accessed 11-6-2014).

7 Prabowo is a former special forces commander who has been accused of human rights abuses, including involvement in an operation in East Timor in 1983 and the abduction of anti-government activists in 1998 (Van Klinken 2014; Aspinall 2015). 'APKLI ibaratkan Prabowo-Hatta paduan sinergi Majapahit-Sriwijaya', Tribun News, 18-52014, http://www.tribunnews.com/pemilu-2014/2014/05/18/apkli-ibaratkan-prabowo -hatta-paduan-sinergi-majapahit-sriwijaya (accessed 10-6-2014). 'APKLI: Tak ada lagi penggusuran PKL jika Prabowo memimpin', Kompas, 2-6-2014, http:// regional.kompas.com/read/2014/06/02/1928409/APKLI.Tak.Ada.Lagi.Penggusuran.PKL .jika.Prabowo.Memimpin (accessed 10-6-2014).

10 'Jokowi ingkar janji, PKL alihkan dukungan ke Prabowo-Hatta', Tribun News, 7-5-2014, http://www.tribunnews.com/pemilu-2014/2014/05/07/jokowi-ingkar-janji-pkl-alihkan -dukungan-ke-prabowo-hatta (accessed 10-6-2014).

11 'Dialogue with vendors "key" to relocation', Jakarta Post, 4-3-2014, http://www .thejakartapost.com/news/2014/03/04/dialogue-with-vendors-key-relocation.html (accessed 10-6-2014). 
Prabowo-Hatta and APKLI. Ali Mahsun made a public announcement to the newspapers, promising to provide approximately 20 million street vendor votes for Prabowo-Hatta. ${ }^{12}$

Edward Aspinall has argued that we must take popular agency more seriously in our understanding of post-authoritarian Indonesia and that the democratic transition was 'essentially driven from below' (Aspinall 2013b:102). He suggests that the agency of the lower political class has been written off far too quickly because scholars have tried to follow models from Europe and Latin America and that they '[had missed] many avenues for lower-class political agency and influence that ha[d] been open throughout the transition' (Aspinall 2013b:103). Aspinall identifies some key avenues for lower-class political influence that have emerged in post-authoritarian Indonesia, such as 'fragmented activism' and 'electoral populism' (Aspinall 2013b:103). He argues that despite fragmentation, the influence and mobilization of these groups is significant and that many politicians 'reinvent themselves by offering policy concessions to poor voters' (Aspinall 2013b:103). With many authors focusing on the role of elites and oligarchs, Aspinall has argued for the need to pay attention to the place of lower-class groups and their interests in shaping Indonesian politics.

We answer Aspinall's (2013b) call by examining the politics of the poor in Indonesia during election periods. In this article we examine the possibilities and limits of clientelism during local and national elections, the role of intermediaries, and the achievements and failures of these moves, through an analysis of the contradictions in local branches of a street vendor association. We use the case of APKLI to understand how politics works at the local level. The organizing of street vendors at the national, regional, and locals levels is occurring in the context of clientelism: a 'practice of exchanging votes for favours' (Gay 1998:7).

We explore why and how street vendors in Yogyakarta City started generating more formal organizations in the 1980 s with the help of student activists, and formed APKLI, a corporatist organization (King 1982) that was represented at the provincial and national levels in the 1990s. Through APKLI, student activists played an important role in mediating street vendors' relationships with the state and the reigning political party, Golkar, during the New Order. As a corporatist organization, APKLI prevented the emergence of more polarized groups that would challenge the state's power (King 1982:116).

12 'Prabowo-Hatta dijanjikan 20 juta suara PKL', Kompas, 30-5-2014, http://regional.kompas .com/read/2014/05/30/1600578/Prabowo-Hatta.Dijanjikan.20.Juta.Suara.PKL (accessed 10-6-2014). 
Since Reformasi, new mediators with close political party ties are helping traders to make political contracts. We describe how, in the 2014 presidential election, one APKLI leader sought to mobilize all APKLI branches to support a particular presidential candidate. Although some APKLI national leaders are seeking to develop an 'imagined community' (Anderson 1983) of street vendors across the archipelago, street vendors remain a disjointed group because many APKLI members continue to express loyalty to local patrons, while others would like APKLI to remain politically neutral. Therefore, while political patrons are looking for clients (voter groups) and their brokers are often interested in facilitating this relationship, the masses are less convinced. Instead, only a small number of clients, those who are part of the broker's 'inner circle', are strongly tied to their patrons (Auyero 2001:180). Although street vendors do not obtain any greater rights through these linkages, they do gain access to some resources, legitimacy, and hence protection by placing themselves in these relationships.

Lindquist $(2015 \mathrm{~b})$ argues that in order to understand brokerage as a historically situated system, there is a need to examine the relationship between figures and types, or between example and theoretical exemplar. In his article, he makes a point of distinguishing between the broker, as a sociological type, and the figure, as a real person who 'embodies the structures of feeling of a particular time and place' (Lindquist 2015b:167). Taking our cue from Lindquist, we examine the role of the broker in helping to negotiate patron-client relationships through two main figures. We use the term 'broker' to refer to a 'party who mediates between other parties' (Lindquist, Xiang, and Yeoh 2012:8) or a person who is 'in-between and has the capacity to make new connections (and divides) and conjure up particular worlds-in-the-making' (Højer and Bandak 2015:14). Brokers often make up a diverse group whose approaches to work and relationships with the state vary widely (Lindquist, Xiang, and Yeoh 2012:8). ${ }^{13}$

The first broker figure is not a street trader but helps to facilitate the relationships between street vendor organizations and politicians, resulting in a 'two-tiered clientelism' (Arias 2007:111). ${ }^{14}$ These individuals are less involved

13 See Lindquist 2015a and 2015b for a discussion of the history of brokers in anthropological studies. He argues against the common view that brokers have typically been considered as 'inherently amoral if not immoral' (Lindquist 2015 b: 163).

14 Desmond Arias (2007) shows how in Rio de Janeiro politicians give favours to traffickers, who then pass these on to residents. He describes this as 'two-tiered clientelism', and argues that 'this decreases the ability of favela residents, who during much of the late twentieth century could choose which local leaders would represent them to politicians, to effectively negotiate for patronage during elections' (Arias 2007:111). 
in daily problem-solving networks, and their influence is, as Olivier de Sardan (2005) observes in his study of development agents, strongly linked to their capacity for partnership and negotiation with outside parties. The second figure is a street trader who is often appointed leader of a traders' organization at the local level and who mediates the traders' relationship to brokers or directly to patrons. This second type of broker has become more common at the local level, as external brokers have trained street vendor leaders in how to navigate municipal government bureaucracies and political parties. These street vendor brokers play an important role in facilitating problem-solving networks through regular interactions with their clients and patrons (Auyero 2001), and generally provide a more direct link between street vendors and patrons.

This article is based on fieldwork conducted from 2006 to 2008 in Yogyakarta, and then again in 2013 and 2014 for two one-month periods by the main author and researcher, Sheri Lynn Gibbings. Elan Lazuardi and Khidir Marsanto Prawirosusanto have helped to collect data during brief periods in 2014, 2015, and 2016. Interviews and participant observation were conducted with street vendors in Yogyakarta City as well as other districts in the province of Yogyakarta. Fieldwork was conducted with the leaders of street vendor organizations, their NGO supporters, and regular traders who are not especially active in street vendor organizations. Additional information was collected and analysed from newspapers and social media sites such as Facebook and Twitter about AP KLI National and its local branches as well as about the leader of APKLI National, Ali Mahsun, who uses a range of social media platforms. We examined these social media outlets, which were publicly available, to see the kinds of posts that AP KLI National, its local branches, and Ali Mahsun published, what was talked about, and particularly how the upcoming election was discussed. ${ }^{15}$

15 APKLI National and its local branches are not very active on social media. Their Facebook page, which is open to the public, was last updated in 2013 with a cover photo of their leaders (https://www.facebook.com/Asosiasi-Pedagang-Kaki-Lima-Indonesia-APKLI -163224833846348/, accessed 10-01-2017). At the local level, a number of APKLI branches maintain public blogs, but these blogs are also rarely updated. APKLI's national leader, Ali Mahsun, is relatively more engaged with social media than the organization itself. Monitoring the Twitter hashtag \#apkli provides the opportunity to follow discussions among a wider range of Twitter users about issues related to street vendors. 


\section{The Political Organizing of Street Vendors}

During the authoritarian period (1966-1998), political organization in Indonesia was severely limited. The government's main concern was stability and development, and NGOs were viewed as bodies that could cause unrest (Hadiwinata 2003). In the late 1970 s and early 1980 , however, members of the growing middle class took an interest in working with and starting NGOs. By the 1990s there was a growing NGO sector in Indonesia, especially in Yogyakarta City with its strong student presence (Hadiwinata 2003). There were many different kinds of NGOs, some of which supported Soeharto's regime and its development paradigm and others that were more critical, but the New Order government's strong approach to 'order' and 'security' forced them all to appear and act non-politically (Ganie-Rochman and Achwan 2005). Years of working under these political conditions generated particular conventions about what politics were and should be, and led to the development of certain ways of acting and communicating politically (Ryter 2009:183).

In 1998, Indonesia underwent a transition to democracy after 32 years of authoritarian rule. This was followed by a process of decentralization (Schulte Nordholt 2005), which has given local governments more control over determining their policies toward street vendors. Since that time, most municipal governments have developed a series of regulations around vending for their city. ${ }^{16}$ With the transition to democracy, street vendors have been able to increasingly take advantage of the greater space available to organize and mobilize in defence of their interests. Many work closely with non-governmental or legal aid organizations to seek greater rights (Gibbings 2016, 2013a, 2013b). A flourishing but fragmented activism around street vendors has followed these social, political, and economic changes. Many vendors who face problems of eviction oppose the government without widespread support from other traders, but often with the help of lawyers or NG Os (Gibbings 2016, 2013a, 2013b). Legal aid organizations often help street vendors because they are interested in protecting their human rights and in helping them to secure their right to livelihood. From our experience, some legal aid organizations and NG Os would like traders to be more organized, have a stronger voice, and therefore be able

16 Since 1999, Indonesia has undergone a decentralization programme, shifting major functional responsibilities, resources, and staff to local governments. Undang-Undang Republik Indonesia Nomor 22 Tahun 1999 tentang Pemerintahan Daerah or Republic of Indonesia Law Number 22 Year 1999 on Regional Government established the decentralization programme. This reform was partly a response to the highly centralized state under Soeharto (Hadiz 2004; McCarthy 2004; Schulte Nordholt 2005). 
to influence politics, because there is unity and strength in numbers. Others, however, may have close ties to the government and help to facilitate a relocation or eviction (Gibbings 2013a).

Despite the desire among some street vendors and NGOs for unity, street traders are an extremely diverse group. In Yogyakarta City, the street traders on Malioboro Street, a major tourist destination, have strong organizations and close ties with the government. Most of the traders have government permits and are therefore considered legal. The traders lucky enough to own or rent a kiosk on Malioboro Street also have relatively high incomes in comparison to other vendors across the city. Although the reality for street vendors differs from street to street and neighbourhood to neighbourhood, Malioboro Street traders can be contrasted generally with traders elsewhere in the city who have a smaller customer base. Most traders in the city remain illegal. They sell their merchandise while on the lookout for the civil service police. Their incomes are much smaller, sometimes only enough to survive. Beyond economic and legal differences, street vendors in Yogyakarta City often distinguish themselves based on ethnicity. Some traders consider themselves as primarily Javanese and dislike traders who have arrived from other parts of Indonesia to sell in Yogyakarta. These outsiders are often characterized as keras (harsh) and wealthy in comparison to the Javanese traders.

Despite their failure to organize broadly as a movement, street vendors have recently exercised surprising leverage through informal links to electoral politics. In 2012, Susilo Bambang Yudhoyono (sBY) passed a Peraturan Presiden (Presidential Regulation) arguing for the Koordinasi Penataan dan Pemberdayaan Pedagang Kaki Lima (Coordination and Empowerment of Street Vendors), and other cities have followed suit, although these regulations have mixed effects. Despite their claim to empower traders, they also give governments the ability to relocate them. In Jakarta, Governor Basuki Cahya Purnama (Ahok) issued Peraturan Gubernur Provinsi Daerah Khusus Ibukota Jakarta No. 10 Tahun 2015 tentang Penataan dan Pemberdayaan Pedagang Kaki Lima (Gubernatorial Regulation no. 10/2015, on Street Vendor Coordination and Empowerment), which provided a government agency with the power to register all vendors, assign them to designated areas, and grant them access to banks. ${ }^{17}$ In August 2014, however, APKLI criticized the Jakarta administration for excluding some traders from its registration system, and for evic-

17 Dewanti Wardhani, 'One year later, street vendor system moves forward', Jakarta Post, 75-2015, http://www.thejakartapost.com/news/2015/05/07/one-year-later-street-vendor -system-limps-forward.html\#sthash.oaTXhoYw.dpuf (accessed 6-4-2016). 
ting street vendors in several regions across the city without providing them with alternative locations. ${ }^{18}$

During the New Order era, Soeharto was the central and most powerful patron, and access to resources or opportunities depended on having the right connections to his office or people (Kusno 2010). When Soeharto fell, power was decentralized, and traditional patron-client relations were disrupted (Brown and Wilson 2007). In post-Soeharto Indonesia, patron-client networks remain important, however, ${ }^{19}$ and are perhaps increasingly prevalent (Aspinall 2014b). ${ }^{20}$ With regard to elections, Aspinall (2014a) describes how 'almost everywhere, candidates complained about how Indonesian voters have become increasingly "pragmatic" or "transactional", and how they are unprepared to vote for people who do not provide them with a tangible material benefitmoney or some other gift'. Much of this vote buying is not done by candidates themselves but by brokers or members of a candidate's 'success team' (tim sukses), who have access to a wide variety of social networks (Aspinall 2014b:103).

Social networks such as street vendor organizations are widespread in Indonesia, and can be used for electoral purposes. Street vendors sometimes have organizational leaders who become brokers, but in other cases NG Os or lawyers take up this role (Gibbings 2013a). Street vendors sometimes receive gifts from potential clients, such as money, tents, or carts, but some organizationsespecially those vulnerable to relocation or eviction-seek out political contracts, a promise that they will not be evicted in exchange for political support. Relationships with patrons are formed not only for the vendors' survival, but also because being part of a network (jaringan) in the city provides them with certain amount of status and respectability.

18 'Association protests street vendor eviction', Jakarta Post, 5-8-2014, http://www .thejakartapost.com/news/2014/08/05/association-protests-street-vendor-eviction.html (accessed 27-3-2016).

19 For further analyses of patron-client networks, see Aspinall 2013a, 2014a, and 2014b; Van Klinken 2009; and Simandjuntak 2012.

20 Deasy Simandjuntak, for instance, has described how despite being able to vote for district heads directly in 2005, local elites have secured these positions by using 'moneypolitics; ethno-religious identities, and elite symbolic power, such as wealth and charisma' (Simandjuntak 2012:95). 


\section{Seeking Political Contracts}

Political contracts-bargains between leaders and street vendor organizations at the local and provincial levels - are increasingly common, and a growing number of intermediaries are helping to facilitate these relationships. The political contract is a new phenomenon in Indonesian politics, and has not been discussed much in the scholarly literature, although it has been widely deliberated on Twitter. The term 'contract' implies as degree of accountability, and this is indeed what is emphasized in online discussions of political contracts. As opposed to money politics, political contracts tend to be seen in a more positive light. Discussions around political contracts on Twitter generally appear in the time leading up to an election. News stories are published on which candidates have made political contracts, and with whom..$^{21}$ Citizens then turn to social media to discuss or disseminate information about these political contracts. Prabowo Subianto, for instance, claimed to be the first vice-presidential candidate to sign political contracts when he was paired with Megawati for the 2009 election. ${ }^{22}$ His Facebook account published a post titled 'Kontrak politik Mega-Prabowo untuk rakyat Indonesia ...' (Mega-Prabowo political contracts with the people of Indonesia). He wrote that political contracts were not a false promise, but a guarantee and agreement that candidates were responsible for fulfilling. In that same post, several scanned pictures of his political contracts were uploaded, including those with labourers, farmers, and Lapindo mudslide victims. ${ }^{23}$

People showed their appreciation for the fact that Mega-Prabowo had made a political contract in the comments on this post. Some remarked how brave they were, and that it indicated a new era of leadership. Others questioned if

21 For example, a candidate for district head (bupati) in Musirawas Utara recently made a political contract stating that he would build infrastructures at the sub-district levels. 'Calon bupati kontrak politik dengan masyarakat', Selasar Politik: Connecting Ideas, 29-92015, https://www.selasar.com/politik/calon-bupati-kontrak-politik-dengan-masyarakat (accessed 8-2-2016).

22 'Prabowo teken kontrak politik dengan nelayan', Vivanews, 20-6-2009, http://politik.news .viva.co.id/news/read/68418-prabowo_teken_kontrak_politik_dengan_nelayan (accessed 11-2-2016).

23 The Lapindo mudslide is said to have started at the Lapindo Inc. mining site in Sidoarjo, East Java Province in 2006 and covered approximately 15 villages in three districts. Wahyoe Boediwardhana, 'No money for Lapindo victims before Idul Fitri', Jakarta Post, 27-6-2015, http://www.thejakartapost.com/news/2015/o6/27/no-money-lapindo-victims-idul-fitri .html (accessed 10-01-2017). 
such contracts had legal implications, and asked about the kinds of sanctions that were available if the pair did not act as promised, as well as asking if the contracts had a deadline. In general, discussions around the practice of political contracts in Indonesia often cast doubt on the actual effects and implementation of political contracts because they are not legally binding. ${ }^{24}$

Despite concerns over legal recourse, street vendor organizations are starting to think more about making political contracts. A group of lawyers in Yogyakarta who often help traders negotiate with the government explained to us that in the last mayoral election the traders had made a political contract with Haryadi, the mayor of Yogyakarta elected in 2011. This contract had not been made with APKLI but with a number of trader organizations across the city. In exchange for support from street traders, the municipal government would not evict pre-existing traders. Since this political contract was made, the lawyer had noticed that it was easier for the street vendors to ask the sub-district head (camat) to facilitate the creation of organizations for street vendors and for the group to ask the districts for monetary support. The goal for the future, however, was to get a political contract in written form to make it more enforceable.

In July 2013, these legal advocates were helping the traders think about how they might prepare for the 2014 elections. In the opinion of Marini, a lawyer, it was too bad that the traders were unable to make a commitment to support a single candidate. She said it was 'not clear [who the traders should support] because they all seemed to have their own interests and different backgrounds'. Marini referred to the time when the Persatuan Pedagang Kaki Lima Yogyakarta, (Association of Street Vendors in Yogyakarta, PPKLY) had formed the contract with the political party Gerindra, and how those traders who had not been involved had not been accommodated. 'There is tug-of-war [tarik ulur] between the different street vendor organizations, and this is the weakness of our friends', she explained. ${ }^{25}$

Since the fall of Soeharto, some street vendors and their supporters are seeking more accountability and power through the formation of political contracts, which are viewed as stronger, more formal, and more explicitly stated than traditional patron-client relationships. In practice, political contracts provide certain street vendor organizations with greater protection from eviction (at least temporarily) or a 'closeness' that they can utilize in order to

\footnotetext{
24 'Kontrak politik dan politik kontrak', Rektivoices .. Site of Widiya Ayu Rekti ..., 13-4-2010, https://rektivoices.wordpress.com/2010/04/13/kontrak-politik-dan-politik-kontrak/ (accessed 20-11-2015).

25 Interview with Sheri and Elan, 16-7-2013, Yogyakarta.
} 
request a programme or help from the government. At the same time, since they are often made with particular organizations based on certain streets, and not with traders as a collective group, they risk inhibiting the growth of programmes and policies in which the interests of all citizens and traders are represented.

Although street vendor organizations, legal aid organizations, and NG Os are present to advocate for their members' interests, not all of Yogyakarta's street traders are interested in joining these organizations or in using them for political gain. Mang Jaja, for instance, who comes from Tasikmalaya in West Java, has an angkringan (food stall) on C. Simanjuntak Street in downtown Yogyakarta. For the past 20 years, Mang Jaja admits he has never been involved in political matters such as elections for village head, city mayor, legislative members, or president. He also never wants to be involved with street vendor organizations. To his knowledge, no street traders in the area have ever been involved in political activities related to legislative candidates. For him, the reason is simple. No one can guarantee to a street trader that he will be able to keep working in a particular area, in spite of his involvement with a political party or street vendor organization. Nearly all street vendors in his area have an agreement locally, such as with orang kampung (the people in the neighbourhood), the village government to whom they have to pay retribution money, and the shop owners whose terraces they use as selling spaces every night. ${ }^{26}$ These relationships appear to be more important to the traders in this region, as they can sell peacefully without an official political contract.

\section{The Role of Mediators and the Formation of APKLI}

Dwight King has described how during the New Order one of the features of the 'bureaucratic-authoritarian regime' was the use of corporatist organizations to limit and control opposition to the regime (King 1982:111). Corporatist organizations were 'noncompeting, officially sanctioned functional organizations' which agents of the state bureaucracy oversaw (King 1982:115). ${ }^{27}$ King (1982:112) argued that corporatism helped to structure the relationships between civil society and the state, and between groups within civil society. In the 1970s,

26 Informal talk with Khidir, March 2015, Yogyakarta.

27 King (1982:114-5) argues that corporatism is a useful framework for enabling us to understand a larger number of New Order political structures and processes than clientelism alone, since not all organizations are clientelistic. 
organizations for groups such as farmers, women, labourers, and teachers were formed one after another.

APKLI can be considered as one such 'semi-autonomous' corporatist organization that was formed during the New Order. Student activists who were members of Lembaga Swadaya Masyarakat (LSM, the Indonesian term for NGOs) that were closely tied to the government first helped the traders organize themselves into associations and cooperatives in order to seek a closer and more positive relationship with the New Order government. Like others, APKLI helped to assemble the street vendors in order to protect and improve their livelihoods while also preventing them for mobilizing in more radical ways that might challenge state power (King 1982:116).

In 1981 a number of university students had dinner in a satay street stall in front of Yogyakarta's Bethesda Hospital. Cak Fai, the owner, heard the students talking about poverty. He reprimanded them by saying, 'Hey you, don't just discuss this! Try to think about our fate!' His statement surprised the students, as they had never heard any street vendor talking about poverty so boldly. The students were members of the Dwarawati Cultural Institute (DCI) in Kotabaru, an organization that was focused on empowering (pemberdayaan) rural and urban citizens by gathering certain community groups into organizations (paguyuban), studios (sanggar), and cooperatives. A few days later, they invited Cak Fa'i for a discussion on the daily life of street vendors, particularly their relationship with government. This discussion inspired the students to think about the importance of street vendor organizations. At one of those meetings, they founded PPKLY. However, the organization could not effectively negotiate with the government and needed further legitimacy, which prompted the idea to establish a cooperative. ${ }^{28}$ The cooperative was named Koperasi Persatuan Pedagang Kaki Lima Yogyakarta (K-PPKLY) and was inaugurated in $1981 .{ }^{29}$

According to an APKLI archive, this cooperative was able to run several programmes for street vendors, including credit distribution and training. ${ }^{30}$

28 Forming a cooperative was an effective way to lobby the government without being 'political'. Cooperatives were not political organizations, but they were officially recognized by the government. It was easier to get government recognition for, or approval of, cooperatives than other types of organizations, especially mass organizations (organisasi kemasyarakatan).

29 The establishment of K-PPKLY was a strategy used to respond to the government's negligence of street vendors' well-being (APKLI 2004:1-3). Imam, interview with Khidir, 31-32016, Yogyakarta. 
K-P PKLY argued that through these programmes members of the cooperative were positioned more strongly in relationship to the government: they were often invited in meetings to discuss urban planning and were given a twostorey building in Yogyakarta to use as an office by the minister of cooperatives (menteri koperasi dan UKM). Street vendor cooperatives also emerged in other provinces, such as the Koperasi Pedagang Kakilima Jatinegara (Kopkalimaja) in Jakarta. Even though street vendor cooperatives started appearing across Indonesia, there was no national organization to oversee them at that time. The traders did not have direct relationships with their patrons either, but worked through brokers, largely 'student activists', who helped to negotiate and maintain these relationships.

In 1985 PPKLY became an ancillary group of a national consortium of NGOS called the Konsorsium Nasional Pusat Pengembangan Masyarakat (PPM, National Consortium for the Development of the People) since many of PPKLY's activist founders were also part of this group. ${ }^{31}$ In cooperation with PPM, PPKLY organized a national seminar on the informal sector, and established a Jaringan Sektor Informal (JSI-PPM, Informal Sector Network). This idea was then translated into another plan to found a national association of informal sector workers (APKLI 2004). In 1993, 127 representatives attended the first National Convention of Indonesian Street Vendors from 18 Indonesian provinces. ${ }^{32}$ During this three-day meeting, Forum Koperasi Pedagang Kakilima se-Indonesia (FOR KOPKINDO, Indonesian Street Vendor Cooperatives Forum) and APKLI-PPM were established. ${ }^{33}$ The satay seller Cak Fa'i was appointed as leader of both organizations (FORKOPKINDO and APKLI-PPM 1993).

Alongside Cak Fa'i, Imam, one of their brokers, was elected as the first Secretary General of APKLI-PPM and FORKOPKINDO. Imam was born in 1965 in Bondowoso, East Java, to Madurese parents who were affiliated with Muhammadiyah. Imam, as a member of PPM, oversaw the First Congress of APKLI in

(LRPM-UII or the Community Development and Research Unit from Universitas Islam Indonesia) assisted K-PPKLY.

31 The PPM was composed of a consortium of 61 local NGOS (LSM), including the DCI and the LRPM-UII, from nine provinces that were supported financially by Murdiono, the secretary of state during the New Order era. Once the PPM was formed, the functions of the DCI were wholly taken on by the PРM and it ceased to exist.

32 At that time, Indonesia had 27 provinces (currently there are 34). Four provinces could not send their delegates due to limited financial resources.

33 APKLI-PPM is one of 14 autonomous bodies built by PPM around the 1990s. (APKLI 2004:i; PPM n.d.: 1-12). 
Yogyakarta. Imam explained why he became a leader, even though he was not a street trader: 'The reason I became the Secretary General [of APKLI-PPM] at the time was because the street vendors had little experience of organizing things and their knowledge of politics was so minimal that they needed assistance from us. ${ }^{34}$ Through this relationship, Imam and the other PPM leaders developed strategies and helped to guide the traders. Imam explained:

We positioned Cak Fai as an actor, a symbol of street vendor struggle, since he was the one who appeared in public, on stage, and during negotiations with the government. Other PPM officials and I were positioned backstage to think, plan, and formulate strategies. [We] prepared the infrastructure of this organization. We were also the ones who prepared what Cak Fa'i should say in each forum. I used to meet Cak Fa'i alone before each public forum. We were indeed fortunate to have him. Although he only completed his secondary education, he was very clever. He was a fast learner. He could articulate ideas well with an advanced rhetoric. ${ }^{35}$

As a broker, Imam helped to translate between the two worlds. He helped to teach Cak Fa'i how to speak and how to formulate strategies that the government would listen to and respect. During the Soeharto era, AP KLI National and its regional branches were often guided by individuals who were not street vendors, but sought to help mediate their relationship with state bureaucrats by promoting the New Order goals of security, order, and cleanliness. In the postSoeharto era, the role of brokers is shifting, and so is that of the patrons.

The 1997 economic crisis and Reformasi changed APKLI and its umbrella organization, since it was so closely tied with Soeharto's New Order. Imam described how the internal situation of PPM (and thus APKLI) shifted, as almost all of the PPM leaders and their activists joined political parties and became involved in what he called 'practical politics'. Although Imam also joined a political party, he eventually chose to return to Yogyakarta to run a business that makes products out of coconut trees. Imam recounted, 'Everyone was oriented to political practice. I was disappointed because at the end, PPM forgot its original purpose, which is economic empowerment. Our political move is

\footnotetext{
34 This same reason was also behind the decision to name their organization APKLI-PPM, according to the first declaration document (FORKOPKINDO and APKLI-PPM 1993:iii; PPM n.d.: 11$)$.

35 Interview with Khidir, 31-3-2016, Yogyakarta.
} 
also oriented towards public policy, not practical politics. ${ }^{36}$ By practical politics he was referring to the fact that individuals from PPM were channelling their efforts for change through political parties, rather than going through NGOS or ormas such as PPM. APKLI, in his opinion, with its relatively big following, was also becoming more targeted by political parties, whereas FOR KOPKINDO, the cooperative, no longer functioned since PPM National no longer made the street vendor's economic empowerment its main priority. ${ }^{37}$

\section{New Brokers, New Politics}

In the post-Soeharto era APKLI has seen the election of new and different kinds of brokers who are more closely associated with political parties. Basri was elected leader of APKLI DIY in 2010. He was born in 1971 in the eastern part of Aceh. His father worked for Pertamina, an oil company. After attending a pesantren, Basri came to Yogyakarta in 1989 to attend university for the study of comparative religions. Shortly after, he joined Himpunan Mahasiswa Islam, an Islamic student organization that provided him with training to become a leader and administer organizations. In the early 199os Basri was involved in a number of NGOS (LSM and yayasan [foundations]), which were starting to take off in Yogyakarta. He decided to break out on his own and help coordinate the various stakeholders on Malioboro Street in the Paguyuban Kawasan Malioboro (P KM, Malioboro Area Organization). ${ }^{38}$

Basri is on the special staff of the Dewan Perwakilan Daerah Republik Indonesia (DPD-RI, Regional Representative Council). He was elected as leader of APKLI DIY in 2010 because of his close connections to municipal and provincial government officials and the sultan's wife. When Basri became the leader he decided to focus on expanding APKLI outside of Yogyakarta City to the provincial level. He said, 'Up until now we have only been [mostly active]

36 Interview with Khidir, 31-3-2016, Yogyakarta.

37 The Second National Convention for APKLI was held in 1999 in Jakarta, when Cak Fa'i was once again appointed as the chairman of APKLI National; he led the association until 2004. While the First National Convention aimed to consolidate street vendors across the country and to establish APKLI at regional levels, the Second National Convention in Jakarta aimed to establish APKLI branches at the municipal level. Following Cak Fa'i's leadership, the national body of APKLI was led by two other leaders. Subsequently, the Third National Convention was held in Surabaya, where Achmad Rifa'i Abdullah, a member of East Java's Chamber of Commerce and Industry, was appointed as leader until 2011. 
in the city, and Malioboro at the centre of the city.' Basri organized leaders from every district, and saw himself as their motivator. He hoped to leave the organization stronger and to help develop good communication among the different APKLI branches so there would not be any suspicion (kecurigaan) of each other.

At the national level, in 2011, Ali Mahsun was appointed leader in APKLI's Fourth National Convention in Semarang for the period of 2011-2016. ${ }^{39}$ Ali Mahsun was born in the small town of Mojokerto in East Java in 1969. He earned his Bachelor's in Medical Education from Universitas Brawijaya in Malang, East Java, in 1989, and continued his study in immunology at Universitas Indonesia, Jakarta, in 1995. His lifelong involvement in social and political organizations started when he was still in college. He has been involved with organizations both related and unrelated to his medical profession. ${ }^{40}$ Leading up to the 2009 presidential election, he was a deputy in vice-presidential nominee Ir. K.H. Shalahuddin Wahid's success team. Through his active involvement in ormas such as Skuad Elang Emas 335 and Barindo, he was also involved in Susilo Bambang Yudhoyono's success team. ${ }^{41}$ He works with various ormas, especially during elections, to ensure a particular candidate's success.

Working alongside Ali Mahsun was Heru Juwono, APKLI's general treasurer. According to Satriyo (APKLI's leader for the Bantul District in Yogyakarta) and others, many disliked Ali's leadership. Hoisa Siregar-the APKLI leader for DKI Jakarta—stated that 24 regional APKLI officials and 164 central board officials cancelled Ali's leadership due to his violations of APKLI's central statute and bylaw. ${ }^{42}$ It was reported that Ali often dismissed APKLI local officials without consulting the statute and bylaw. As a result, members held an Extraordinary National Convention in Jakarta in 2013, where Heru Juwono was chosen to replace Ali Mahsun as the leader of APKLI. ${ }^{43}$ Ali Mahsun did not step down,

39 Lasiman (chairman of DPW APKLI Central Java) nominated him for this position. 'Who is dokter Ali ketum APKLI?', http://whoisabout.org/ALI-BOCA-CENTRE/

118292938602139072142 (accessed 27-3-2016).

40 He was also a member of the advisory board (dewan pembina) to the Pengurus Besar Ikatan Dokter Indonesia (Indonesian Doctors Association Central Panel) between 2006 and 2009.

'Barindo tak kecewa sBY pilih Boediono: Deklarasikan dukungan untuk sBy Berboedi', JPNN.com, 17-5-2009, http://www.jpnn.com/berita.detail-17968 (accessed 27-3-2016).

'Dr. Ir. Heru J. Juwono terpilih aklamasi sebagai ketua umum APKLI', Jurnal Ibu Kota, 5-52013, https://jurnalibukota.wordpress.com/2013/05/05/dr-ir-heru-j-juwono-terpilih -aklamasi-sebagai-ketua-umum-apkli/ (accessed 27-3-2016).

Satriyo, Interview with Khidir, 12-9-2014, Bantul. 
however, and reported Heru's appointment to the police. ${ }^{44}$ For some APKLI and PPKLY leaders, there appeared to be two leaders on the central board of APKLI. ${ }^{45}$

Under Ali Mahsun's leadership, APKLI began to collect data on street vendors across Indonesia in 2013 in an attempt to better coordinate the vendors. They estimated that there were roughly 22 million traders in Indonesia. The lack of any official database was seen as a major obstacle inhibiting the traders from coordinating as business operators. This coordination would give them strength, and hopefully enable them to get support from the national government. By 2013 there were APKLI groups in 27 provinces, with the aim to soon be operating in six more. ${ }^{46}$ In April 2014 Ali Mahsun declared, 'The time is right for street vendors to have a president' (Saatnya PKL punya presiden). Shortly thereafter, he stated that APKLI would support Prabowo-Hatta in the 2014 presidential election. ${ }^{47}$

Ali Mahsun and Basri are new types of brokers since Reformasi. Not street vendors themselves, they are highly connected, and work to help politicians get elected as members of their success team, whether at the national or local level. For these brokers, street vendors are an important mass that has 'potential', because their numbers are large and they have not yet been overly organized. Rather than helping street vendors in their daily negotiations with the state, however, these brokers are mostly involved during important political moments like elections.

\section{The 2014 Presidential Election: Promising Votes}

Since the shift to democracy in 1998, a significant change has been the introduction of competitive elections. In July 2014, Indonesia was scheduled to hold its third competitive presidential election. Former general Prabowo Subianto was running against the governor of Jakarta, Joko Widodo. With branches of AP KLI

44 Satriyo, Interview with Khidir, 12-9-2014, Bantul. See also APKLI Laporkan Pencatut Organisasi ke Polda Metro Jaya, Gatra News, 5-5-2013, http://www.gatra.com/hukum-1/29742 -apkli-laporkan-pencatut-organisasi-ke-polda-metro-jaya.html (accessed 27-3-2016). Satriyo, Interview with Khidir, 12-9-2014, Bantul.

46 'UKM: Jumlah pedagang kaki lima diperkirakan capai 22 juta orang', Bisnis.com, 5-5-2013, http://industri.bisnis.com/read/20130505/87/12417/ukm-jumlah-pedagang-kaki-lima -diperkirakan-capai-22-juta-orang (accessed 27-3-2016).

47 Fayaddh Abubakar, 'Saatnya PKL punya presiden', RMOL Kantor Berita Politik, 5-4-2014, http://m.rmol.co/news.php?id=149954 (accessed 27-3-2016). 
established throughout the provinces, the traders decided to leverage their numbers and newfound bargaining position. In May 2014, following APKLI National's step to support Prabowo-Hatta, the leaders of APKLI for Yogyakarta Province met to discuss how they planned to support Prabowo-Hatta in the upcoming election. Neta, ${ }^{48}$ who had worked closely with the new leader of APKLI DIY, Basri, since 2000, became responsible for finding locations in each district and city in the province where they could potentially open a post (posko) in the lead-up to the election. She explained their role: 'AP KLI DIY has already made a declaration to support one candidate, Prabowo-Hatta, and DIY is following the commands from the central APKLI in Jakarta. We have started the process of sosialisasi (promoting and informing citizens) and hanging banners. 49

Not all colleagues embraced Ali Mahsun's goal of supporting Prabowo-Hatta, however. Heru Juwono, the APKLI National leader contested by Ali Mahsun after his appointment in the 2013 Extraordinary Convention, requested that groups not use the name of APKLI in support of any candidates in the 2014 election. ${ }^{50} \mathrm{He}$ said: 'Don't hope that you will receive a personal benefit in the name of APKLI from the presidential candidate, because we have already decided not to support the presidential campaign of any camp.' Heru demanded that the 'elements' (oknum) who were using the name of APKLI to support a certain presidential campaign stop their activities immediately. On 12 June, Heru, along with some supporters, reported Ali Mahsun to the police.$^{51}$ Not all brokers (especially those closer to the traders) wanted to support a presidential candidate, because they saw the potential problems. If they supported one candidate too strongly and that candidate did not win, then the traders would be put in a difficult position after the election.

Despite the dissent and the accusations against him, Ali Mahsun continued to mobilize different APKLI groups across the country and was certain that 20

48 Neta was born in Jakarta in 1971. At Universitas Katolik Indonesia Atma Jaya, Jakarta, she took theology and Catholic studies. In 1998, when she finished university, Neta moved to Yogyakarta where she met Basri; they have worked together ever since (interview with Sheri, 12-06-2014, Yogyakarta).

49 Neta, email communication with Sheri, 11-6-2014.

50 'APKLI jangan digunakan untuk ngamen ke capres tertentu', Tribun News, 10-6-2014, http:// www.tribunnews.com/pemilu-2014/2014/06/10/apkli-jangan-digunakan-untuk-ngamen -ke-capres-tertentu (accessed 29-8-2014).

51 'Nama APKLI dipakai dukung salah satu capres, pengurus laporkan Ali Mahsun', Berita Satu, 12-6-2014, http://www.beritasatu.com/pemilu-2014/189792-nama-apkli-dipakai -dukung-salah-satu-capres-pengurus-laporkan-ali-mahsun.html (accessed 29-8-2014). 
million street vendors would give their votes to Prabowo-Hatta. ${ }^{52}$ In Semarang, he was present when 300 leaders of street vendor organizations across the city decided to support Prabowo-Hatta. ${ }^{53}$ In Yogyakarta, APKLI DIY gave its official support to Prabowo-Hatta in an event at the Rumah Merah Putih Indonesia DIY (Red and White House) known as the Deklarasi Gerobak (Cart Declaration). ${ }^{54}$ APKLI DIY's leader, Basri, confirmed that they supported PrabowoHatta because they 'supported the empowerment of street vendors'. Herry Zudianto, former mayor of Yogyakarta (2001-2010), chairman of Red Cross DIY (2011-2016), and close friend of Basri, ${ }^{55}$ had also become a member of PrabowoHatta's success team. ${ }^{56}$ Basri was on Herry Zudianto's success team when he ran for mayor in 2004 and 2008. Basri had helped to mobilize street vendors and other stakeholders on Malioboro Street during the mayoral election.

Herry and Basri decided to create a team supporting Prabowo-Hatta called Tim Gerobak PKL (Street Vendor Cart Team) with the purpose of consolidating traders in Yogyakarta in the leadup to the election. ${ }^{57}$ At the Gerobak Declaration, Herry stated that because people had quickly chosen to support PrabowoHatta in Yogyakarta it meant that there was some trust in Prabowo. ${ }^{58}$ Basri suggested that APKLI had approximately 80,000 voters in the province, and that they would 'disseminate information' on Prabowo-Hatta by going from stall to stall. ${ }^{59}$ Basri and Herry's hopes were quickly dashed, however, as APKLI districts expressed their interests in supporting different candidates. Basri and Herry's mobilization of the traders was not only about securing their votes in

52 '20 juta PKL pilih No 1', Koran Sindo, 24-6-2014, http://m.koran-sindo.com/node/397324 (accessed 29-8-2014).

53 'PKL Semarang sawer Rp 1,1 juta untuk Prabowo-Hatta', Kompas, 23-6-2014, http://regional .kompas.com/read/2014/o6/23/1729208/PKL.Semarang.Sawer.Rp.1.1.Juta.untuk.Prabowo -Hatta (accessed 29-8-2014).

54 Mantan Wali Kota Yogya Jadi Ketua Tim Pemenangan Prabowo-Hatta, 2-o6-2014, http:// www.tribunnews.com/pemilu-2014/2014/06/o2/mantan-wali-kota-diy-jadi-ketua-tim -pemenangan-prabowo-hatta, (accessed 01-15-2017).

55 From 2001 to 2005, Herry Zudianto (PAN) served with Sykuri Fadholi from the Partai Persatuan Pembangunan (PPP, United Development Party) as the vice mayor.

$5^{6}$ 'Prabowo-Hatta ingin wujudkan kedaulatan pangan: Menolak didikte kekuatan asing', Kedaulatan Rakyat, 10-6-2014; 'Mantan wali kota Yogya jadi ketua tim pemenangan Prabowo-Hatta', Tribun News, 2-6-2014, http://www.tribunnews.com/pemilu-2014/2014/o6/o2/ mantan-wali-kota-diy-jadi-ketua-tim-pemenangan-prabowo-hatta (accessed 29-8-2014).

57 'Prabowo-Hatta harus berdayakan PKL', Kedaulatan Rakyat, 18-6-2014.

$5^{8}$ 'Prabowo-Hatta harus berdayakan PKL', Kedaulatan Rakyat, 18-6-2014.

59 'APKLI siap menangkan Prabowo-Hatta', Radar Jogja, 19-6-2014, http://www.radarjogja.co .id/apkli-siap-menangkan-prabowo-hatta/ (accessed 29-8-2014). 
exchange for potential support of policies favouring street traders; it was also a moment in the larger system of social and political relationships in the city (Auyero 2001). Herry and Basri were obliged at least to try to mobilize the street traders because of their own patronage networks.

\section{Local Loyalties and Differing Views about 'Politics'}

Despite AP KLI National's declaration of support for Prabowo-Hatta, local loyalties influenced the decisions of many district branches. After initially agreeing to support APKLI National's decision, the DIY branch eventually conceded that it must allow the district branches to vote for their own choices. Neta described APKLI DIY's difficulty in reaching an agreement with local branches to support Prabowo-Hatta. ${ }^{60}$ For example, in Bantul, Idham Samawi still had significant influence over people in the villages. He was formerly the Bantul district head for two periods (1999-2004 and 2005-2010) and was also the chairman of the Partai Demokrasi Indonesia Perjuangan (PDI-P) at the provincial level. Recently, he was selected as a legislative member for PDI-P. Such conditions made it impossible for APKLI Bantul members to vote for Prabowo-Hatta, since Idham acted on the advisory board (dewan pembina) of APKLI in Bantul and was a loyal supporter of PDI-P-Jokowi's political party.

Satriyo, ${ }^{61}$ the head of APKLI Bantul, explained that Idham and his wife (Sri Surya Widati, successor to the Bantul district head after Idham in the period 2010-2015) helped APKLI Bantul rent their office, which allowed APKLI Bantul to operate their programmes and cooperative. In the 2011 APKLI Regional Convention in Bantul, Satriyo was selected as chairman, and Idham Samawi was appointed as chairman of the board of trustees. Because of Idham's position in the organization, Satriyo said it was obvious all members of APKLI Bantul would vote for Jokowi-JK. ${ }^{62}$ As Idham's confidants, Satriyo and other leaders of APKLI Bantul did not attend the Gerobak Declaration. 'We support you [Basri] morally, but to be there [showing support for Prabowo-Hatta]; it would feel wrong', Satriyo reminisced. Satriyo's relationship with Idham was based on more than mere economic and political exchanges. Their relation-

\footnotetext{
6o Neta, Interview with Elan, 15-9-2014, Bantul.

61 Satriyo was born in 1954 in Gunung Kidul and completed his secondary education. From 2010 to 2015 he was the leader of APKLI Bantul and the head of the street vendor cooperative in Bantul. Satriyo is the only member of PPKLY still alive who witnessed the formation of APKLI Yogyakarta in 1993.

62 Interview with Khidir, 12-9-2014, Bantul.
} 
ship had feelings of mutual aid and friendship, which made going against his patrons feel 'wrong' (Auyero 2001:213).

Satriyo asked APKLI DIY to understand their political choice. Despite differences in political opinions, leaders (pengurus) including Basri were able-or at least forced - to understand each other. Basri did appeal in APKLI forums for the traders to vote for Prabowo-Hatta; however, neither the provincial nor municipal branches of APKLI problematized street traders' eventual choices. APKLI Bantul openly declared their support for Jokowi-JK. Satriyo said: 'Of course, we made a declaration of support. So, after data collection [of APKLI Bantul members] and inauguration of leaders from 13 sub-branches [DPC], we agreed to declare our support for Jokowi. ${ }^{63}$ Satriyo said that he implicitly asked everyone to vote for Jokowi. To do so, he monitored the sub-branch-level meetings. 'Not only did street vendors attend this declaration, I distributed 170 T-shirts for street traders. They were sent to me directly by Idham Samawi, who was in Jakarta at that time. More than 200 people attended. We also made a banner saying APKLI Bantul supports Jokowi,' he explained. ${ }^{64}$

Other APKLI branches also faced similar situations, where influential street vendor leaders were in an opposite position politically. Suhardi, the leader of the city branch, APKLI Kota Yogyakarta, was also invited to meetings held by Basri in the months leading up to the election. However, while street vendors may have felt pressurized into supporting certain candidates, they could not be convinced to follow Basri's suggestion to vote for Prabowo-Hatta. Suhardi, along with Satriyo and leaders from AP KLI Sleman, decided not to attend the declaration day event, citing a difference of political opinion as the reason. Suhardi did not use the organization's name to declare his support, but made it known to members that he supported Jokowi. Unlike Ali Mahsun, he argued, 'I think Jokowi's approach to street traders is still considered soft' — referring to Jokowi's direct communication to street traders. ${ }^{65}$

Suhardi declared his support for Jokowi-JK without acting on behalf of APKLI Kota Yogyakarta. He believed APKLI should have acted politically neutral and that APKLI National's decision to declare their support for PrabowoHatta was elitist - they did not consult with the lower levels. Basri did invite the leaders of each branch for meetings before the declaration, but the decision to support Prabowo-Hatta had already been made. Suhardi explained that when certain people declared support for one candidate on behalf of APKLI,

\footnotetext{
63 Interview with Khidir, 12-9-2014, Bantul.

64 Interview with Khidir, 12-9-2014, Bantul.

65 Interview with Khidir, 11-9-2014, Bantul.
} 
problems could arise: 'Nationally, when APKLI took sides, it can work like a boomerang for APKLI. If AP KLI takes a side, but [the election is] won by another side, APKLI has to start over again the process of negotiation and communication [with the government].' This is why he decided to support Jokowi-JK without using APKLI Kota Yogyakarta's name. While brokers such as Ali Mahsun and Basri imagined that other brokers and street vendors would follow their lead, they underestimated competing beliefs about how and whether street vendor organizations should be involved in politics. They also underestimated the 'structures of feeling' that some brokers and members had toward other brokers and patrons.

During the declaration day event organized by APKLI DIY, traders from all over DIY were invited to join this declaration in support of Prabowo-Hatta. Some paguyuban leaders across the province signed a declaration of support. However, Neta pointed out that nobody knew who would actually vote for Prabowo-Hatta. 'Well, isn't it obvious they would sign when asked to sign? But, what truly happens in the vote box, nobody knows. ${ }^{66}$ This was part of the problem with elections. People might say they supported Prabowo-Hatta, but then vote for someone else. Neta's comment that people would sign if asked also suggests that these exchanges among brokers, clients, and patrons were not as much about obtaining votes as about maintaining social relationships. People would rather sign the document than potentially offend their broker/patron, even if they planned to vote for another candidate.

Beyond the declaration, according to Neta, APKLI DIY did no more to promote through sosialisasi the organization's position in the presidential election. There was only one election post on Pattimura Street in Yogyakarta, which served as the base camp for the Koalisi Merah Putih (Red and White Coalition, KMP) - the coalition of political parties supporting Prabowo-Hatta. There was no 'going from stall to stall', as they originally planned, as they left the district (kabupaten) and city branches to make their own choices once they realized how fragmented the group was. Published information followed the 'official voice' of APKLI DIY, but what happened on election day, only the voters knew.

Neta remarked that the DIY case was unique. The situation differed to that in other places, such as West Sumatra, where, according to her friends, it was easier to reach a consensus. ${ }^{67}$ Similarly, Satriyo was not sure if it was possible to make every street trader in the organization vote for one candidate. ${ }^{68}$ Suhardi

\footnotetext{
66 Interview with Elan, 15-9-2014, Bantul.

67 Interview with Elan, 15-9-2014, Bantul.

68 Interview with Khidir, 12-9-2014, Bantul.
} 
agreed that in Yogyakarta there is not a single political voice among traders. During the New Order, street traders might have felt pressured to vote for one candidate. However, in the Reformasi era, they are more aware of their political rights, and can choose whichever political party is willing to take on their agenda. ${ }^{69}$ The inability of APKLI to reach a consensus is also representative of the larger political polarization that appeared in the runup to the presidential election (Mietzner 2014).

From our interviews with everyday traders, it was obvious that AP KLI did not have much influence. Dulah and Sukir took no interest in the APKLI declaration of support for Prabowo-Hatta. These two men came from the Gunung Kidul district in eastern DIY, which is well known for its water scarcity. Many men in the village come to nearby cities like Yogyakarta and Klaten to do odd jobs when no hard work is necessary in the rice fields. One such job is to become a street vendor. Both Dulah and Sukir acknowledged the existence of APKLI as a street vendor association, but said that they had never been interested in joining. ${ }^{70}$ Sukir argued that becoming a member would only create an unnecessary burden, since fulfilling one's duties as a member took up time. Dulah expressed a similar opinion. He would rather spend his energy focusing on his selling activities. They both said there was no benefit from membership besides more friends and access to cooperatives.

Siti, with her husband Kadir, ran a stall selling fried chicken and fish with her speciality: sambal. Her stall was located near a railway station in Yogyakarta. She had never been involved in a street vendor organization; instead, she was more involved in her neighbourhood association (rukun tetangga), as she lived near her food stall. She did not know what APKLI was, and was not concerned that AP KLI DIY made a declaration to support Prabowo. Many in her neighbourhood supported the Partai Keadilan Sejahtera (Prosperity and Justice Party, PKs) - an Islam-associated political party in coalition with Gerindra; hence many — she assumed — supported Prabowo. Nonetheless, she did not say who she would vote for. ${ }^{71}$

69 This is related to the street vendors lawyers' goal of ensuring that every political party has street vendors on its agenda, thus making it difficult for them to choose just one political party.

70 Interview with Khidir, 11-9-2014, Sleman.

71 Interview with Elan, 14-9-2014, Bantul. 


\section{After the Election}

In July 2014 Joko Widodo was declared the winner of the presidential election with $53.15 \%$ of the vote, while Prabowo Subianto received $46.85 \%$ of the vote. ${ }^{72}$ Yogyakarta was among the 23 provinces where Jokowi-Jusuf Kalla earned more votes than Prabowo. ${ }^{73}$ In DIY a total of $2,245,164$ people voted $(79.84 \%$ of eligible voters), ${ }^{74}$ and Jokowi-JK earned $55.81 \%$ of the votes, earning the majority of votes in all municipalities within the region (both cities and districts). ${ }^{75}$

Six months after the election, Satriyo, one of the original founders of APKLI, encouraged Basri to organize an informal meeting in order to minimize the political differences, and perhaps tensions, that had arisen during the election. Satriyo felt that Basri had become less concerned about, or involved with, APKLI since the election, and that he had been busier with his own activities of writing and giving religious lectures. Since the election, Satriyo had been helping to negotiate new selling locations for street vendors. He had made agreements with two restaurant owners on a major street, Jalan Parangtritis, to give 30 kiosk spaces to street vendors from Bantul to sell souvenirs and speciality foods. He was also involved in the formulation of Bantul's District Regulation (Peraturan Daerah, Perda) on Street Vendor Coordination and Empowerment (Penataan dan Pemberdayaan Pedagang Kaki Lima) and with a District Head Regulation (Peraturan Bupati, Perbup) regarding the Proof of Trading Licences (Tanda Daftar Usaha or TDU). Satriyo negotiated an important role for APKLI in the management of the licences; APKLI would be part of a government committee that would oversee their administration.

Basri and Satriyo are different kinds of brokers. While Basri was involved in organizing meetings among the APKLI branches and in trying to unify the street

72 After the election results were released, Prabowo sought to challenge the results because of alleged widespread electoral fraud, but his accusations were rejected by the Mahkamah Konstitusi (Constitutional Court). See 'Election finally ends for Prabowo', Jakarta Post, 218-2014, http://www.thejakartapost.com/news/2014/o8/21/election-finally-ends-prabowo .html (accessed 6-4-2016).

73 Prabowo won in 11 provinces, including West Sumatra and most other provinces in Sumatra, which appeared to prove Neta's point that it was much easier to reach a consensus in West Sumatra than in Yogyakarta. See 'Ini hasil resmi rekapitualisi suara pilpres 2014', Harian Jogja, 22-07-2014, http://indonesiasatu.kompas.com/read/2014/07/22/20574751/ini .hasil.resmi.rekapitulasi.suara.pilpres.2014 (accessed 29-9-2014).

74 'KPU DIY selesaikan rekapitulasi pilpres dalam waktu dua jam', Komisi Pemilihan Umum, 20-07-2014, http://kpu.go.id/index.php/post/read/2014/3429/- (accessed 29-9-2014). PDI-P is one of the largest parties in Yogyakarta (Choi 2004). 
traders prior to the election, after the election he took a backseat. Satriyo, on the other hand, is deeply embedded in everyday negotiations with shop owners and government bureaucrats in Bantul in order to secure a strong position in relation to the state.

\section{Conclusion}

Edward Aspinall (2013b) argues that we need to pay more attention to the lower classes and to how they are shaping Indonesian politics. We have explored here the role of the street vendor organization APKLI. Formed during the Soeharto era, APKLI was one of the first street vendor organizations, and it had close ties with the New Order regime. Student activists acted as brokers and mediated the relationship between APKLI street vendors and government bureaucrats. They helped to educate and guide street vendors in negotiating their connections with state bureaucrats while also training vendors in how to organize themselves and speak with government officials. The activism during the New Order era was subtle- they did not challenge or critique Soeharto's regime, but sought to create a more favourable atmosphere for traders by generating a closer relationship to the state and promoting and following state ideologies. Our case suggests that street vendors impact politics because politicians view them as a group that can be mobilized during elections. During the New Order, street vendors were mobilized in support of re-electing the New Order's political party, Golkar, in exchange for recognition and support for their cooperatives. Although street vendors were not given specific rights, government support of cooperatives gave them more legitimacy.

In the post-Soeharto era, APKLI brokers are working more closely with political parties rather than government bureaucrats to advocate for street vendors' rights. Although it is too soon to know for certain, this shift suggests that political parties might be gaining greater power. Some APKLI leaders and brokers are starting to imagine the traders as a group that can be mobilized on a larger scale. The formation of a national organization for street vendors has helped this process along with the passage of a Peraturan Presiden No. 125 Tahun 2012 tentang Koordinasi Penataan dan Pemberdayaan Pedagang Kaki Lima (Presidential Regulation no. 12/2012 on Coordination and Empowerment of Street Vendors). This 'imagined community' (Anderson 1983) of like-minded vendors does not play out in practice, however, as street vendors remain a fragmented group. Each APKLI branch has its own unique relationships with political parties and local government officials. Thus APKLI National's attempt to mobilize street vendors toward one party candidate did not succeed, since 
its branches were already embedded in their own patron-broker-client relationships. There were also a number of differences in opinion among the leadership. While some street vendor leaders and brokers are seeking out closer connections to political parties and politicians, others want to avoid the risk and instead focus on economic empowerment and maintaining connections with their traditional patrons, such as government bureaucrats and shop owners.

Our case revealed two types of broker figures that play an important role in mediating the organization of street vendors. First, there are individuals who are not street traders themselves, but have experience organizing groups and connections to political parties or government officials. These brokers are involved in negotiating the relationships between traders and patrons during important moments such as elections, but are less involved in day-today mediations. In this system, political parties or bureaucrats give favours to brokers, which the brokers then redistribute to the street vendors. This results in a 'two-tiered clientelism', in which the brokers are free to negotiate patronage with a number of different political parties, and street vendors are left choosing which brokers they want to support, if any (Arias 2007:111). This two-tiered system reduces the ability of street vendors to formulate direct relationships with politicians and also increases street vendors' reliance on brokers. The second type of broker is the street vendor leader who has become skilled in organizing, and has also developed connections with politicians and bureaucrats. This figure tends to form relationships at the local level with mayors or regents rather than at the regional or national level. Unlike the first type of broker, this figure is 'on the ground' and mediates relationships not only around elections, but also on a daily basis. Such street vendor leaders, like Satriyo in Bantul, strengthen ties between politicians and their street vendor organizations directly.

Further studies into the meaning, effects, and politics of political contracts are needed as such agreements become more common and are discussed across Indonesia. The case of APKLI suggests that political contracts are growing in popularity among marginalized groups such as street vendors; however, perceptions of these contracts among traders and brokers are varied. While some brokers are keen to formulate political contracts in order to secure the position of street vendors, many others are less impressed and continue to prefer to cultivate protective relations with local administrators and businesses, as has always been the case. The people who typically oppose political contracts are traders who see the potential negative fall-out of such agreements. APKLI National's top-down political contract ultimately failed because they did not deliver the votes promised, but it had lasting effects. The APKLI branches 
were more fragmented and divisive after the election, reflecting their different positions in relation to the political contract. Although the traders as a national body were divided, they did have agency insofar as they operated as clients who could decide which broker/patron they wanted to support. While the political contract was made with the intention of helping street traders, it also served a symbolic role of re-enforcing important social and political relationships between patrons, brokers, and clients.

\section{References}

Anderson, B. (1983). Imagined communities: Reflections on the origin and spread of nationalism. London and New York: Verso.

APKLI (2004). Sekilas tentang APKLI. Jakarta: Dewan Pimpinan Pusat APKLI.

Arias, E.D. (2007). 'Routing conflict: Organized violence and clientelism in Rio de Janeiro', in: L. Joseph, M. Mahler, and J. Auyero (eds), New perspectives in political ethnography, pp. 110-34. New York: Springer.

Aspinall, E. (2013a). 'A nation in fragments: Patronage and neoliberalism in contemporary Indonesia', Critical Asian Studies 45-1:27-54.

Aspinall, E. (2013b). 'Popular agency and interests in Indonesia's democratic transition and consolidation', Indonesia 96-1:101-21.

Aspinall, E. (2014a). 'Parliament and patronage', Journal of Democracy 25-4:96-110.

Aspinall, E. (2014b). 'When brokers betray: Clientelism, social networks, and electoral politics in Indonesia', Critical Asian Studies 46-4:545-70.

Aspinall, E. (2015). 'Oligarphic populism: Prabowo Subianto's challenge to Indonesian democracy', Indonesia 99:1-28.

Auyero, J. (2001). Poor people's politics. Durham, nc: Duke University Press.

Brown, D. and I.D. Wilson (2007). 'Ethnicized violence in Indonesia: Where criminals and fanatics meet', Nationalism and Ethnic Politics 13-3:367-403.

Choi, N. (2004). 'Local elections and party politics in post-Reformasi Indonesia: A view from Yogyakarta', Contemporary Southeast Asia 26-2:28o-301.

FORKOPKINDO and APKLI-PPM (1993). Hasil-hasil musyawarah nasional pedagang kaki lima Indonesia. Yogyakarta: FOR KO P KINDO and APKLI-PPM.

Ganie-Rochman, M. and R. Achwan (2005). 'Inclusion and exclusion: NGOs and critical social knowledge', in: V.R. Hadiz and D. Dhakidae (eds), Social science and power in Indonesia pp. 197-220. Jakarta and Singapore: Equinox Publishing.

Gay, R. (1998). 'Rethinking clientelism: Demands, discourses and practices in contemporary Brazil', European Review of Latin American and Caribbean Studies 65:7-24.

Gibbings, S.L. (2013a). 'Unnamed interests and informal leaders: A street vendor relocation in Yogyakarta City', Indonesia 96:151-85. 
Gibbings, S.L. (2013b). 'Unseen powers and democratic detectives: Street vendors in an

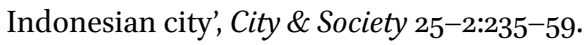

Gibbings, S.L. (2016). 'Street vending as ethical citizenship in urban Indonesia', Anthropologica 58-1:77-94.

Hadiwinata, B. (2003). The politics of NGOs in Indonesia: Developing democracy and managing a movement. London: Routledge Curzon.

Hadiz, V.R. (2004). 'Decentralisation and democracy in Indonesia: A critique of neoinstitutional perspectives', Development and Change 35-4:697-718.

Højer, L. and A. Bandak (2015). 'Introduction: The power of example', Journal of the Royal Anthropological Institute 21-1:1-17.

King, D.Y. (1982). 'Indonesia's New Order as a bureaucratic polity, a neopatrimonial regime or a bureaucratic-authoritarian regime: What difference does it make?' in: B. Anderson and A. Kahin (eds), Interpreting Indonesian politics: Thirteen contributions to the debate, pp. 104-16. Ithaca, NY: Cornell University Press.

Klinken, G. van (2009). 'Decolonization and the making of middle Indonesia', Urban Geography 30-8:879-97.

Klinken, G. van (2014). 'Prabowo and human rights', Inside Indonesia 116:1-28.

Kusno, A. (2010). The appearances of memory: Mnemonic practices of architecture and urban form in Indonesia. Durham and London: Duke University Press.

Lindquist, J. (2015a). ‘Brokers and brokerage, anthropology of', in:James D. Wright (ed.), International encyclopedia of the social and behavioral sciences, pp. 1-14. Oxford: Elsevier.

Lindquist, J. (2015b). 'Of figures and types: Brokering knowledge and migration in Indonesia and beyond', Journal of the Royal Anthropological Institute 21-51:162-77.

Lindquist, J., B. Xiang and B.S.A. Yeoh (2012). 'Opening the black box of migration: Brokers, the organization of transnational mobility and the changing political economy in Asia', Pacific Affairs 85-1:7-19.

McCarthy, J.F. (2004). 'Changing to gray: Decentralization and the emergence of volatile socio-legal configurations in Central Kalimantan, Indonesia', World Development 32-7:1199-223.

Mietzner, M. (2014). 'How Jokowi won and democracy survived', Journal of Democracy 25-4:111-25.

PPM (Pusat Peranserta Masyarakat). (n.d.). Sekapur sirih. Jakarta: P PM Nasional.

Ryter, L. (2009). 'Their moment in the sun: Indonesia's new parliamentarians from the old oKP', in: G. van Klinken and J. Barker (eds), The state of authority in Indonesia, pp. 181-218. Ithaca, NY: Cornell Southeast Asia Program Publications.

Sardan, J.-P.O. de (2005). 'Mediations and brokerage', in: Anthropology and development: Understanding contemporary social change, pp. 166-84. London and New York: Zed Books.

Schulte Nordholt, H. (2005). 'Decentralisation in Indonesia: Less state, more democ- 
racy?', in: J. Harriss, K. Stokke, and O. Törnquist (eds), Politicising democracy: The new local politics of democratisation, pp. 29-50. London: Palgrave Macmillan UK.

Simandjuntak, D. (2012). 'Gifts and promises: Patronage democracy in a decentralised Indonesia', European Journal of East Asian Studies 11:99-126. 